\title{
ASERTIVNO UPRAVLJANJE LJUDSKIM RESURSIMA U KNJIŽNICI
}

\author{
ASERTIVE HUMAN RESOURCES \\ MANAGEMENT IN LIBRARIES
}

\author{
Dubravka Čanić \\ Medicinska škola Karlovac \\ dubravka.canic@gmail.com
}

\author{
UDK / UDC \\ 005.96:027: 159.9 \\ Stručni rad / Professional paper \\ Prihvaćeno / Accepted: 18.6.2017.
}

\section{Sažetak}

Cilj je ovog rada prikaz asertivnog upravljanja ljudskim resursima u knjižnici. Asertivnost u upravljanju važna je osobina jer omogućuje ravnateljima knjižnice uspješno rukovođenje institucijom i zaposlenicima. Asertivno upravljanje knjižnicom manifestira se kroz pozitivan stav, izravnu komunikaciju te učinkovitost u poslovanju. Zadatak ravnatelja knjižnice jest poticanje i motiviranje kolektiva te uspješna organizacija poslovanja. Asertivan ravnatelj knjižnice član je tima, kompetentan je, poštuje profesionalnu etiku i sposoban je donositi ispravne poslovne odluke.

Ključne riječi: upravljanje knjižnicom, asertivnost, upravljanje ljudskim resursima, emocionalna inteligencija

\section{Summary}

The aim of this paper is to present assertive management of human resources in libraries. Assertiveness in management is an important feature because it allows directors of libraries a successful management of the institution and staff. Assertive library management is manifested through a positive attitude, direct communication, and business

Vjesnik bibliotekara Hrvatske 60, 2-3(2017), 279-293

ISSN 0507-1925

(C) VBH 2017. 
efficiency. The task of the director of the library is to encourage and motivate the team and to establish successful business organization. An assertive director of the library is a key member of the team, is competent, respects professional ethics, and is capable of making the right business decisions.

Keywords: library management, assertiveness, human resource management, emotional intelligence

\section{Upravljanje ljudskim resursima i opći moralni principi u ruko- vođenju}

Asertivno ponašanje jest ponašanje koje ljudima omogućuje da se izbore za sebe i za svoj interes, a da pritom ne nanose štetu drugim ljudima. Asertivni ljudi ne srame se reći što žele niti im postojanje vlastitih potreba stvara nelagodu. Asertivno se ponašanje manifestira kroz pozitivan stav, izravnu komunikaciju, orijentiranost prema postizanju konkretnih ciljeva i sposobnost za socijalnu interakciju. Asertivni ljudi posjeduju empatiju, odnosno sposobni su se uživiti u tuđu situaciju i razumjeti druge ljude. ${ }^{1}$ Upravljanje nekom institucijom, pa tako i knjižnicom, uvjetovano je individualnim osobinama pojedinaca, tipom osobnosti, odnosom prema radu, motivacijom, znanjem, ali i psihologijom grupe koja određuje model odnosa u organizaciji. Uspjeh kolektiva ovisi o sposobnosti ravnatelja da motivira i organizira osoblje.

Zadatak je ravnatelja objašnjavanje zadataka i ciljeva, poticanje kolektiva, planiranje i organiziranje radnog procesa, rješavanje administrativno-tehničkih pitanja, uspješno stvaranje timova, davanje potpore zaposlenicima, poticanje efikasnosti kolektiva, kontroliranje procesa rada, vršenje pritiska s ciljem poticanja kolektiva, dodjeljivanje zadataka, definiranje ciljeva i zaduženja te nagrađivanje dobro obavljenih poslova pohvalom. Uspješan ravnatelj član je tima, olakšava ljudima posao, podučava, brani, vodi, uči cijeli život, specijalizira se u raznim područjima, cijeni sposobnost i dobre rezultate, kompetentan je, posjeduje komunikacijske vještine, donosi odluke u dogovoru s kolektivom, spreman je surađivati i dijeliti važne informacije sa suradnicima. Ravnatelj je dužan pridržavati se poslovne etike te imati hrabrosti i volje za donošenje ispravnih odluka. On mora biti sposoban procijeniti koji je poslovni potez moralan i opravdan. ${ }^{2}$

\footnotetext{
1 Agada, John; Kenneth Weaver. Empathy, assertiveness and professional socialization in library education [citirano: 2016-02-01]. Dostupno na http://rportal.lib.ntnu.edu.tw/bitstream/77345300/15589/1/ntnulib_ja_A1201_2302_001.pdf.

2 Vodopija, Štefanija. Opća i poslovna komunikacija : priručnik i savjetnik za uspješnu komunikaciju. Rijeka : Naklada Žagar, 2006.
} 
Upravljanje ljudskim resursima obuhvaća zapošljavanje, davanje uputa, preraspodjelu dužnosti, organizaciju poslovnih aktivnosti, motiviranje djelatnika, komuniciranje i administrativne funkcije. To je strategija upravljanja zaposlenicima jedne institucije s ciljem da se poveća učinkovitost i produktivnost te da se ostvare zadani ciljevi. Osoba zadužena za upravljanje ljudskim resursima ima širok spektar dužnosti: zapošljavanje i osposobljavanje djelatnika, razvoj organizacije, komunikacija, podučavanje i mnoge druge. Specifične dužnosti unutar neke institucije jesu: planiranje poslovnih aktivnosti i raspodjela dužnosti kako bi se ostvarili zadani ciljevi, organizacija rada, upravljanje zaposlenicima, davanje uputa, vođenje tima i pružanje podrške u radu, provjeravanje radnog procesa i evaluacija izvršenih zadataka. ${ }^{3}$

Upravljanje ljudskim resursima u knjižnici odnosi se na stvaranje visokomotiviranog, kvalificiranog i profesionalnog osoblja orijentiranog na korisnika. Izrazito je važno da se ravnatelj knjižnice ponaša asertivno, da ima stav i da zna prepoznati specifične talente pojedinih zaposlenika te ih, na temelju njihovih predispozicija, primjereno preraspodijeliti na funkcije i poslove koji njihovom karakternom profilu najbolje odgovaraju. Asertivan ravnatelj znat će prepoznati najbolje radnike, nagraditi ih, pridržavat će se procedure u poslu, osigurat će pozitivnu klimu na poslu i optimalan radni učinak, a svoj će entuzijazam prenijeti na zaposlenike. Upravljanje ljudskim potencijalima objedinjuje poslove vezane uz ljude, njihovo regrutiranje, izbor u zanimanja, obrazovanje i poslovni razvoj. Osoba zadužena za upravljanje ljudskim potencijalima mora znati integrirati zaposlenike, izgraditi grupnu koheziju, biti fleksibilna i stimulirati zaposlenike. Funkcije upravljanja ljudskim potencijalima jesu: zapošljavanje, profesionalni razvoj, poticanje uspješnosti u poslu, otkrivanje menadžerskih potencijala i integracija u području ljudskih potencijala. ${ }^{4}$

Funkcija zapošljavanja obuhvaća analizu radnih mjesta, regrutiranje i selekciju zaposlenika te uvođenje novozaposlenih u posao. Uspješan ravnatelj mora znati preraspodijeliti kadrove, pribaviti zaposlenike i osposobiti ih za daljnji rad, poticati uspješnost poslovanja (motivirati, poticati kreativnost, evaluirati i nagraditi najbolje). Zadatak je uspješnog ravnatelja prepoznati karakter zaposlenika (koliko je tko pouzdan, poduzetan, komunikativan, kreativan, učinkovit) i povremeno davati zaposlenicima povratne informacije vezane uz posao koji su odradili i uz međusobne odnose unutar tima. Ravnatelj mora rukovoditi ustanovom i zaposlenicima na demokratski način kako bi se osigurala sloboda rada i autonomija odlučivanja. Ravnatelj mora znati odabrati, trenirati i osposobljavati zaposlene,

\footnotetext{
3 Heathfield, Susan. M. What is human resource management [citirano: 2016-02-01]. Dostupno na http://humanresources.about.com/od/glossaryh/f/hr_management.htm.

4 Upravljanje ljudskim potencijalima [citirano: 2016-02-01]. Dostupno na http://www.poslovniforum.hr/management/upravljanje_ljudskim_potencijalima.asp.
} 
voditi sastanke i diskusije, upravljati konfliktom, pregovarati na ravnopravnoj osnovi i integrirati rad svih zaposlenika ustanove. ${ }^{5}$

Postoje opći moralni principi kojih se osoba koja upravlja nekom institucijom mora pridržavati, a to su dignitet ljudskog života i autonomnost - mogućnost i pravo svake osobe na slobodan odabir i ostvarenje svojih prava i vrijednosti; poštenje - istina mora biti dostupna svima; dosljednost - obećanja, ugovore i obveze treba poštovati (ravnatelj mora održati zadanu riječ i obećanja, odgovorno se ponašati, osigurati kvalitetan rad, biti pouzdan, ponašati se u skladu sa zakonom); pravednost - treba se držati zakona, nikoga se ne smije diskriminirati, prema svima treba imati jednak pristup; humanost - činiti dobro i izbjegavati zlo, biti sposoban za empatiju i opće dobro - voditi se načelnom dobrobiti za većinu, ali pritom poštovati i štititi prava pojedinca. ${ }^{6}$

\section{Emocionalna inteligencija i sastavnice emocionalne kompetencije}

Uspješan ravnatelj mora imati dobro razvijenu emocionalnu inteligenciju. Emocionalna inteligencija sposobnost je osobe da realizira sebe i međuljudske odnose na zreo i konstruktivan način. Emocionalna inteligencija ogleda se kroz samosvjesnost i samoprihvaćanje te kroz socijalnu svjesnost, odnosno kroz sposobnost osobe da osjeti tuđe osjećaje i shvati tuđe potrebe, kroz znanje o organiziranju, inspirativno vođenje, kroz sposobnost upravljanja konfliktom te kroz volju za suradnjom i radom u timu. Izrazito je važno da ravnatelj posjeduje te kvalitete jer se uspješnost tima ogleda kroz unutarnju međuovisnost u donošenju odluka, raspodjelu odgovornosti, zajedničko donošenje odluka, dobru komunikaciju, kreativnost i naglašen fokus na inovaciji i budućnosti. ${ }^{7}$

Emocionalna inteligencija sposobnost je motiviranja samog sebe, ustrajavanje unatoč teškoćama i frustracijama, sposobnost obuzdavanja impulzivnosti i odgađanja trenutka primanja nagrade, sposobnost reguliranja svojih raspoloženja i onemogućavanje uzrujanosti da zaguši sposobnost razmišljanja, suosjećanja i suradnje. Osobe s dobro razvijenim emocionalnim vještinama bit će zadovoljnije, učinkovitije i produktivnije te sposobnije za autorefleksiju i empatiju. Empatija se temelji na svijesti o tome što osjeća druga osoba, a ta svijest djeluje u širokom spektru životnih područja, kako na intimnom planu tako i u poslovnom svijetu. To je osobita vrsta suosjećanja, sposobnost uživljavanja u emocionalno stanje drugih ljudi te razumijevanje njihova položaja. Emocionalna inteligencija sastoji se od četiri zasebne sposobnosti: organiziranja skupina, dogovaranja kompromisnog rješenja, stvaranja osobnih veza i društvene analize.

\footnotetext{
5 Isto.

6 Isto, str. 31.

7 Isto, str. 198.
} 
Organiziranje skupina vitalna je osobina vođe, a sastoji se od iniciranja i koordiniranja napora mreže ljudi te preuzimanja vodstva u odlučivanju. Dogovaranje kompromisnog rješenja talent je posrednika koji sprečava sukobe ili rješava već nastale sporove. Osobe koje posjeduju tu sposobnost utječu na sklapanje sporazuma, arbitražu ili posredništvo u sporovima te su diplomati. Emocionalno inteligentna osoba lako će ostvariti osobne veze te prepoznati i primjereno reagirati na tuđe osjećaje i brige. To su osobe koje su sastavni dio tima, pouzdani poslovni partneri i izvrsni upravitelji. Imaju dobro razvijene socijalne vještine, pa uspješno organiziraju timove i rješavaju konflikte. Emocionalno inteligentne osobe prirodno su nadarene vođe koje znaju artikulirati ciljeve grupe. ${ }^{8}$

Emocionalna kompetencija ima dvije komponente: osobnu kompetenciju i društvenu kompetenciju. Osobna se kompetencija sastoji od samosvijesti (emocionalne svjesnosti, točne samoprocjene i samopouzdanja), samosvladavanja (samokontrole, vjerodostojnosti, savjesnosti, prilagodljivosti, inovativnosti) i motiviranosti (težnje za postignućem, predanosti, inicijative, optimizma). Društvena se kompetencija ogleda kroz empatiju, razumijevanje i potpomaganje drugih, utjecajnost, komunikativnost, uspješno razrješavanje sukoba, vodstvo, poticanje promjena, stvaranje veza, suradnju i premnost na timski rad. Emocionalne kompetencije uspješnih ravnatelja jesu: samosvladavanje, savjesnost, pouzdanost, društvene vještine, građenje veza i njegovanje različitosti. ${ }^{9}$

\section{Asertivno ponašanje}

Asertivno ponašanje jest ponašanje koje ljudima omogućuje da se izbore za sebe i svoj interes, a da pritom ne nanose štetu drugim ljudima. Asertivni ljudi ne srame se reći što žele niti im postojanje vlastitih potreba stvara nelagodu. Takvo se ponašanje manifestira kroz pozitivan stav, izravnu komunikaciju, kroz orijentiranost prema postizanju konkretnih ciljeva i sposobnost za socijalnu interakciju. Asertivni ljudi posjeduju empatiju, odnosno sposobni su se uživiti u tuđu situaciju i razumjeti druge ljude. Interpersonalna asertivnost ogleda se kroz način na koji osoba reagira u situacijama u kojima se njezini interesi sukobljavaju s interesima drugih ljudi. Ljudi reagiraju na različite načine: izbjegavaju konflikt, ponašaju se pasivno, ekstremno su agresivni ili hostilni. Asertivnost se nalazi na sredini kontinuuma. Asertivnost se ogleda kroz volju pojedinca da se zauzme za vlastiti interes i ideje i za vlastite ciljeve. To je sposobnost osobe da se odupre tuđim ponašanjima koja joj idu na štetu. ${ }^{10}$

8 Goleman, Daniel. Emocionalna inteligencija : zašto može biti važnija od kvocijenta inteligencije. Zagreb : Mozaik knjiga, 1997.

9 Isto, str. 33.

10 Ames, Daniel. Pushing up to a point : assertiveness and effectiveness in leadership and interpersonal dynamics [citirano: 2016-02-01]. // Research in Organizational Behavior 29 (2009), str. 112. 


\section{Etika pregovaranja i poslovanja i utjecaj karakternih osobina na etičnost u poslovanju i upravljanju}

Etika se odnosi na opće socijalne standarde o tome što je u određenoj situaciji ispravno, a što pogrešno ili na proces određivanja tih standarda. Ona se razlikuje od morala koji se odnosi na individualna i osobna vjerovanja o tome što je ispravno, a što pogrešno. Etika proizlazi iz određenih filozofija koje općenito služe za definiranje prirode svijeta u kojem živimo i određivanje pravila za zajednički život u tom svijetu. U praksi se odnosi na procjenu strategija i metoda u poslu i pregovaranju. Možemo razlikovati etiku krajnjeg rezultata, odnosno etiku odabiranja određenih postupaka na temelju rezultata koje želimo postići, etiku dužnosti (odabir određenih postupaka na temelju dužnosti pridržavanja određenih pravila i načela, pridržavanje zakona), etiku socijalnog ugovora (odabir određenih postupaka na temelju normi, vrijednosti i strategija organizacije u kojoj radimo) i osobnu etiku (osobna uvjerenja, savjest). ${ }^{11}$

Postoje karakterne dimenzije koje utječu na neetičnost, odnosno etičnost ponašanja: 1. sklonost natjecanju ili sklonost suradnji - osobe koje su agresivne i sklone natjecanju koriste blefiranje, lažno prikazuju informacije i koriste se obmanom u komunikaciji, za razliku od osoba koje su sklone suradnji. Osobe sklone rivalstvu koristit će etički dvojbene metode i bit će sklone manipuliranju i laganju. 2. Makjavelizam - pragmatično i sebično shvaćanje ljudske prirode. Osobe koje posjeduju tu karakternu osobinu sklone su manipulaciji. Smatraju da je najbolje reći ljudima ono što oni žele čuti i da je teško napredovati bez povremenog kršenja pravila. Izrazito makjavelistički nastrojeni pojedinci majstori su prevare koji će lagati kad god je to potrebno i pritom neće osjećati tjeskobu, pa će zbog toga njihove laži zvučati uvjerljivo. Makjavelizam je dobar prediktor neetičnog ponašanja. 3. Lokus kontrole - ljudi se razlikuju prema lokusu kontrole, odnosno prema stupnju u kojem vjeruju da je sve što postižu rezultat njihove sposobnosti ili rezultat sudbine. Ljudi s unutarnjim lokusom kontrole vjeruju kako imaju veću kontrolu nad postizanjem rezultata u situacijama u kojima bi se mogli ponašati neetično, pa takvo ponašanje i situacije i izbjegavaju. ${ }^{12}$

\section{Stilovi upravljanja konfliktom}

Karakterne razlike utječu na stil upravljanja konfliktom i stil pregovaranja, na socijalnu vrijednosnu orijentaciju, interpersonalno povjerenje, samoefikasnost, lokus kontrole, makjavelizam i osjetljivost na prijetnju ugledu. Stil upravljanja

Dostupno na http://www.columbia.edu/ da358/publications/ames_pushing_up_to_a_point.pdf.

11 Lewicki, Roy. J; David M. Saunders; Bruce Barry. Pregovaranje. 5. izd. Zagreb : Mate, 2009.

12 Isto, str. 262. 
konfliktom ovisi o stupnju asertivnosti kojim osoba nastoji ostvariti željena rješenja i rezultate i stupnju sklonosti suradnji koji strana pokazuje prema radu s drugom stranom u postizanju zajedničkih ciljeva.

Ako se spoje te dvije dimenzije, dobit ćemo pet glavnih stilova upravljanja konfliktom: 1. natjecanje (visoko na asertivnosti, nisko na suradnji); 2. prilagodba (nisko na asertivnosti, visoko na sklonosti suradnji); 3. izbjegavanje (nisko i na asertivnosti i na sklonosti suradnji); 4. suradnja (visoko i na asertivnosti i na sklonosti suradnji) i 5. kompromis (umjereno i na asertivnosti i na sklonosti suradnji).

Socijalna vrijednosna orijentacija može biti individualistička (egoistična) i prosocijalna (suradnička). Makjavelistički nastrojeni ljudi cinični su prema tuđim motivima, nisu skloni altruizmu i empatiji te su manje spremni mijenjati svoja uvjerenja pod socijalnim pritiskom. Kognitivne sposobnosti također utječu na sposobnost i etičnost pregovaranja. Kognitivna sposobnost vrlo je općenita sposobnost rasuđivanja, planiranja, razumijevanja složenih ideja, brzog učenja i učenja iz iskustva. Kognitivna sposobnost utječe na rasuđivanje, donošenje odluka, procesiranje informacija, učenje i prilagođavanje promjenama, osobito $u$ novim situacijama. ${ }^{13}$

Pasivan stil ophođenja zasniva se na nastojanju da se izbjegne konflikt pod svaku cijenu. Ljudi koji komuniciraju na taj način ne govore puno, ne postavljaju puno pitanja i ništa ne poduzimaju. Imaju nisko samopoštovanje i nisu u stanju izboriti se za svoj interes. Internaliziraju neugodne stvari u želji da ne uzrujaju druge ljude. Osoba je preplavljena osjećajem krivnje, osjeća se kao gubitnik i žrtva. Pasivna osoba dopušta drugim ljudima da njome upravljaju. Nema autoriteta, pa ju ljudi najčešće ili žale ili preziru. ${ }^{14}$ Pasivna je osoba submisivna te izbjegava konflikt pod svaku cijenu. Ljudi ju percipiraju kao mlakonju, slabića. Zamjeraju joj indiferentnost i nesigurnost. Pozitivne osobine ogledaju se u brizi za druge ljude. Submisivna osoba rado pomaže drugim ljudima, dio je tima, suosjećajna je, nesebična i ljubazna. ${ }^{15}$

Agresivni stil ophođenja uvijek uključuje manipulaciju. Osobe koje preferiraju taj stil ophođenja koriste zastrašivanje i kontrolu kako bi zadovoljile isključivo vlastite potrebe. Drugi ih ljudi ne zanimaju. Ne poštuju druge ljude jer im nedostaje minimum empatije. Agresivna je osoba egocentrična, teži zadovoljiti isključivo svoje potrebe, drugim ljudima nameće osjećaj krivnje, nanosi im štetu, iskorištava ih, ne vjeruje drugima, eksplozivna je i hostilna. Ljudi koji s njom rade osjećaju ili ljutnju ili strah. D. Ames navodi u svom radu opis agresivnog

\footnotetext{
13 Isto, str. 384.

14 Ames, Daniel. Nav. dj., str. 115.

15 Cornelius, E. T. Leadership styles for dealing with people [citirano: 2016-02-01]. Dostupno na https://www.yumpu.com/en/document/view/10187170/leadership-styles-for-dealing-with-people-collegiate-project-.
} 
upravitelja koji su dali zaposlenici koji su imali nesreću raditi s njim: „Pretjerano je zahtjevan, šovinist, ne prihvaća ne kao odgovor, zastrašuje one koji su u hijerarhiji ispod njega, nedostaje mu karizme i drugih ljudskih osobina.“ „Bio je nepristojan, grub i sklon kontroliranju. Smatrao je da on jedini ima nešto vrijedno za reći i nije želio saslušati tuđa mišljenja. Nije imao upravljačke vještine, osjećaja za planiranje.“ „Bio je totalni nasilnik. Fokusiran na zastrašivanje ljudi, uvjeravao ih je da su počinili kardinalne greške, umjesto da im ukaže kako da bolje odrade stvari. Uopće nije bio zainteresiran za izgradnju snažnog tima koji bi ga podupirao. Nije dobro obavljao posao. “16

Pasivno-agresivni stil ophođenja predstavlja kombinaciju prva dva tipa. Pasivna osoba izbjegava izravnu konfrontaciju, ali se osvećuje kroz razne oblike manipulacije i sabotaže. Osoba namjerno ne izvršava zadatke u zadanom roku, pretvara se da je nešto zaboravila napraviti, namjerno je neučinkovita, sklona je širenju tračeva i neistina te stvaranju negativnog ozračja u kolektivu. Pasivno-agresivna osoba ima nisko samopoštovanje, izbjegava odgovornost, ne trudi se dovoljno, željna je pohvala, nedostaje joj empatije, uvijek su joj svi drugi krivi, odbija se prilagoditi, latentno je hostilna, osjećaje izražava neizravno, zbunjuje druge ljude te stvara kod njih osjećaj frustracije, ljutnje i nepovjerenja. Osoba izbjegava izravan sukob, neorganizirana je, odgađa i posao i obveze, nedovoljno je izravna, ne zna se obraniti, netolerantna je i smatra da je pametnija no što to zaista jest, sebična je i želi prvo namiriti sebe; ne može obaviti ni svoj posao, a kamoli tuđi, nema osjećaj za upravljanje, nema baš puno znanja u svom području i nije u stanju biti dio tima. Pasivna je osoba submisivna te izbjegava konflikt pod svaku cijenu. Ljudi ju percipiraju kao mlakonju, slabića. Zamjeraju joj indiferentnost i nesigurnost. Pozitivne osobine ogledaju se u brizi za druge ljude. Submisivna osoba rado pomaže drugim ljudima, dio je tima, suosjećajna je, nesebična i ljubazna. ${ }^{17}$

Asertivna osoba ima visoku razinu samopoštovanja i samopouzdanja. Ona komunicira izravno, bez manipulacija i poigravanja. Spremno preuzima odgovornost za svoje postupke. Asertivna je osoba tolerantna, optimistična, ne gazi preko ljudi da bi stigla do cilja, spremno priznaje pogrešku, svjesna je svojih kvaliteta i mana, vjeruje drugim ljudima i osjećaje izražava mirno i autentično, a ljudi ju poštuju. ${ }^{18}$

\section{Stilovi upravljanja knjižnicom}

Zaposlenici svake knjižnice razlikuju se po psihičkim osobinama i svjetonazoru. Neki su inhibirani, neki agresivni, a neki nekooperativni. Pasivne upravljačke

16 Ames, Daniel. Nav. dj., str. 115.

17 Cornelius, E. T. Nav. dj., str. 3.

18 Handbook on communication skills [citirano: 2016-02-01]. Dostupno na http://www.slideshare.net/RDC2/handbook-on-communication-skills. 
tehnike generiraju nezadovoljstvo i nepoštovanje unutar tima, a agresivne kreiraju defanzivno ponašanje, nepovjerenje i hostilnost. Rješenje je $u$ asertivnim tehnikama koje dopuštaju menadžerima da zadrže svoja prava i dužnosti, ali i da pritom poštuju prava i dužnosti ostalih. U knjižnicama rade karakterno različiti ljudi, pa uvijek postoje konflikti i napetosti unutar kolektiva. Iako upravitelji održavaju formalno jedinstvo, unutar svakog kolektiva postoji određena doza napetosti i hostilnosti. Upravo zbog toga upravitelji knjižnica moraju biti sposobni nositi se s konfliktima i ostalim problemima u poslu na inteligentan način, odnosno moraju se naučiti ponašati asertivno. Prema Hulbert, tri su glavna stila upravljanja knjižnicama: pasivno, agresivno i asertivno upravljanje.

Ravnatelji koji na pasivan način upravljaju knjižnicom jesu, prema Hulbert, oni koji toleriraju neprikladno ponašanje, loše radne navike, neispunjavanje zadataka u zadanom roku i nelogično razmišljanje te izbjegavaju izravno nošenje s problemima. Kako bi iskazali nezadovoljstvo, pasivni upravitelji iznose općenite komentare usmjerene na cijelu grupu, a ne na pojedince, izbjegavaju probleme, ignoriraju tuđe propuste te čak odrađuju tuđe poslove kako bi izbjegli konflikt. Izbjegavaju iznositi svoje stavove i komentare, pa zaposlenici nemaju povratnu informaciju o obavljenom poslu. Problemi se gomilaju, a osoblje sve manje i manje poštuje upravitelja. Dolazi do pada morala na poslu, a i upravitelj je nezadovoljan jer sve ono što ga smeta nije u stanju izravno izreći. Prema Hulbert, agresivan stil rukovođenja knjižnicom može biti manifestan ili latentan, suptilan. Temeljna karakteristika tog stila rukovođenja jest nedostatak poštovanja prema drugim ljudima. Agresivni upravitelji donose prebrzo odluke i zaključke o uzrocima problema, uvijek optužuju druge za probleme koji su nastali, nisu u stanju saslušati tuđe ideje i sugestije, pretjerano reagiraju na probleme, uvijek su u pravu, ne zanimaju ih tuđi prioriteti te izbjegavaju kompromise. Najčešće imaju problem s kontrolom ljutnje. Ekstremni oblici agresivnog upravljanja izuzetno su štetni za kolektiv i pojedince. Rezultat agresivnog upravljanja vidljiv je kroz defanzivno ponašanje zaposlenika, prekid slobodnog strujanja ideja, narušenu komunikaciju, nedostatak timskog rada i osjećaja pripadanja timu. Agresivno ponašanje stvara klimu prepunu nepovjerenja, demoralizacije, hostilnosti i antagonizma. Agresivno upravljanje može stvoriti velike dugoročne probleme. Prema Hulbet, za razliku od pasivnih upravitelja, asertivni upravitelji preuzimaju odgovornost za svoje postupke, žele osigurati da svi zaposlenici znaju što se od njih očekuje i kao od pojedinaca i kao od članova tima. Oni rješavaju probleme učinkovito, ali bez gaženja tuđih prava i svjetonazora. Asertivne tehnike jesu: slušanje kako bi se shvatila srž problema, izricanje jasnih pravila, fokusiranje na rješavanje važnih problema, pregovaranje i spremnost na kompromis, strpljenje i spremnost davanja pozitivne kritike i ohrabrenja te pohvale za dobro obavljen posao. Upravitelj knjižnice koji se ponaša asertivno sposoban je saslušati druge ljude i njihove probleme bez da ih osuđuje, zna izreći izravno ono što misli i sposoban je postaviti 
jasne standarde ponašanja unutar tima. Sposoban je donositi ispravne zaključke, riješiti pojedinačne probleme i artikulirati željene rezultate, jasno definirati i upoznati članove tima s rasponom njihovih odgovornosti i autoriteta. Asertivan upravitelj spreman je na kompromis i pregovaranje te je dosljedan i strpljiv. Svjestan je činjenice da se ljudi razlikuju te da ih ne smije osuđivati zbog njihovih svjetonazora i karakternih osobina. ${ }^{19}$

Koliko je važna emocionalna inteligencija i asertivnost u poslu i životu općenito, vidljivo je iz sljedećeg primjera. U svojoj knjizi Emocionalna inteligencija u poslu Daniel Goleman navodi primjer asertivnog ponašanja knjižničarke. „Na samom početku 70-ih, dok su diljem svijeta studentski prosvjedi protiv rata u Vijetnamu bili najsnažniji, knjižničarka koja je radila u inozemnoj podružnici Informacijske agencije SAD-a primila je lošu vijest: skupina studenata prijetila je da će zapaliti knjižnicu. No knjižničarka je poznavala neke studente aktiviste iz skupine koja je prijetila. Njezin je odgovor, koji bi se na prvi pogled mogao pričiniti naivnim ili neodgovornim - ili pak oboje - bio poziv studentima da svoje sastanke održavaju u prostorijama knjižnice. No isto je tako tamo dovela i Amerikance koji su živjeli u toj zemlji kako bi ih saslušali - i tako je potaknula dijalog umjesto sukoba. Postupivši tako, knjižničarka je zapravo za obostranu dobit iskoristila svoje poznanstvo sa šačicom studentskih vođa, poznanstvo dovoljno da bi im vjerovala, kao i oni njoj. Ta je taktika otvorila puteve međusobnog razumijevanja, a ojačala je i njezino prijateljstvo sa studentskim vođama. Knjižnica nije pretrpila nikakvu štetu. Knjižničarka je pokazala vještinu nenadmašnog pregovarača i mirotvorca, sposobnog očitati kretanja u tenzijama, munjevito preokrenuti situaciju i pronaći način kako ljude spojiti umjesto da se suprotstave. Ustanova u kojoj je radila izbjegla je oštećivanje kakvo se desilo drugim sličnim američkim ustanovama izvan SAD-a, a koje su vodili ljudi slabijih društvenih umijeća. Knjižničarka se našla u grupi mladih diplomata koje je State Department proglasio superzvijezdama i koje je podrobno promatrao tim stručnjaka pod vodstvom profesora Davida McClellanda s Harvarda.“

\section{Komunikacijske vještine kao dio knjižničarskih kompetencija}

Komunikacijske vještine spadaju u temeljne vještine knjižničara, posebice onih koji rade u korisničkim službama. ${ }^{20}$ Kod narodnih knjižnica trima najpoželjnijim kompetencijama smatraju se komunikativnost, pretraživanje i pronala-

19 Hulbert, Doris. Assertive management in libraries [citirano: 2016-02-01]. // Journal of Academic Librarianship 16, 3 (1990), str. 159. Dostupno na http://cdigital.uv.mx/bitstream/123456789/5949/1/A12.pdf.

20 Lukačević, Srđan; Kornelija Petr Balog. Trebamo li mijenjati svoje komunikacijske vještine? Primjer Gradske i sveučilišne knjižnice Osijek. // Vjesnik bibliotekara Hrvatske 56, 1-2 (2013), str. 153. Dostupno i na http://hrcak.srce.hr/index.php?show=clanak\&id_clanak_jezik=170275 [citirano: 2017-06-17]. 
ženje informacija te obrada građe. ${ }^{21}$ Knjižničari moraju posjedovati dobre komunikacijske vještine jer je kvalitetna komunikacija temelj za uspješno obavljanje posla u cjelini. Da bi zaštitile korisnike i zadržale profesionalnu komunikaciju, knjižnice nužno moraju razviti vlastiti etički kodeks. Knjižničari u komunikaciji s korisnicima predstavljaju knjižnicu, a svaka profesija podrazumijeva usvajanje posebnih i vrijednih znanja i vještina. ${ }^{22}$ Komunikacija ima veliku važnost u pružanju boljih usluga korisnicima. Knjižničari kao profesionalci prenose vrijednost knjižnične usluge korisnicima. Kada pružaju informacije korisnicima, oni moraju jasno i pošteno komunicirati s njima, moraju uvijek pokazivati aktivne vještine slušanja pri komuniciranju kako s korisnicima tako i s kolegama na svom radnom mjestu. ${ }^{23}$ Pojam kompetencije teško je jednoznačno definirati. Kompetencije su zbroj znanja, vještina, sposobnosti, motivacija, uvjerenja, vrijednosti i interesa, a odnose se na zaposlenje i poslovne rezultate te se mogu usavršiti vježbom i izobrazbom. ${ }^{24}$ Predložena kompetencijska matrica za programe izobrazbe knjižničara koja je izrađena u okviru projekta „Cjeloživotno učenje knjižničara“ sadrži u sebi dio koji se odnosi na poslovne vještine te dio koji se odnosi na generičke i opće kompetencije. Poslovne vještine koje su identificirane kao relevantne jesu vještine upravljanja radnim procesima, vještine marketinga, vještine i metode javnog zagovaranja, znanja primjene sustava kvalitete, vještine suradnje među institucijama i partnerima. Generičke i opće kompetencije jesu vještine koje se odnose na ljude (komunikacija, timski rad, uslužne vještine), upotreba računalne tehnologije, konceptualne vještine, osobne vještine (odgovornost, fleksibilnost, upravljanje vremenom, samoprocjena), poduzetničke vještine (inovativnost, motivacija) i socijalne vještine/stavovi (građanska angažiranost, socijalna odgovornost). ${ }^{25}$ Najznačajnija generička kompetencija po mišljenju knjižničara upravo su komunikacijske vještine. Generičke kompetencije također najviše cijene i ravnatelji knjižnica. Knjižničari su mišljenja kako su organizacijske sposobnosti i vje-

21 Petr Balog, Kornelija; Ivana Martinović. Na tragu ishoda učenja: kompetencije diplomiranih knjižničara Odsjeka za informacijske znanosti u Osijeku. // Vjesnik bibliotekara hrvatske 52, 1 (2010), str. 14. Dostupno i na http://hrcak.srce.hr/index.php?show=clanak\&id_clanak_jezik=123548 [citirano: 2017-06-17].

22 Lukačević, Srđan; Kornelija Petr Balog; Dubravka Pađen Farkaš. Asertivnost i komunikacija u knjižničnom okruženju: primjer Gradske i sveučilišne knjižnice Osijek. // Libellarium 9, 1 (2016), str. 93. Dostupno i na http://libellarium.org/index.php/libellarium/article/view/245 [citirano: 2017-06-17].

23 Swapna G.; B. S. Biradar. Competencies for library professionals in digital environment. // e-Library Science Research Journal 5, 2 (2016), str. 3. Dostupno i na http://lsrj.in/UploadedArticles/764.pdf [citirano: 2017-06-17].

24 Machala, Dijana. Knjižničarske kompetencije. // Cjeloživotno učenje knjižničara : ishodi učenja i fleksibilnost / ur. Aleksandra Horvat i Dijana Machala. Zagreb : NSK, 2009. Str. 91.

25 Machala, Dijana; Tatjana Nebesny; Aleksandra Horvat. Kompetencijska matrica. // Cjeloživotno učenje knjižničara : ishodi učenja i fleksibilnost / ur. Aleksandra Horvat i Dijana Machala. Zagreb : NSK, 2009. Str. 131. 
štine upravljanja te sposobnost prilagodbe novim situacijama najslabije usvojene generičke kompetencije tijekom školovanja. ${ }^{26}$ Kompetencije koje knjižničar treba imati kako bi uspješno i u skladu sa standardima struke obavljao svakodnevne poslove dijele se na instrumentalne, interpersonalne i sistemske. Instrumentalne su kompetencije sposobnost analize i sinteze, sposobnost organiziranja i planiranja, temeljno opće znanje, utemeljenost znanja u struci, usmena ili pisana komunikacija na materinskom jeziku, znanje drugog jezika, osnovne vještine uporabe računala, vještina prikupljanja i upravljanja informacijama, rješavanje problema i odlučivanje. Interpersonalne su kompetencije kritičke i samokritičke sposobnosti, uvažavanje različitosti i multikulturalnosti, sposobnost rada u međunarodnom okruženju, etička predanost, međuljudske vještine te timski rad. Sistemske su kompetencije sposobnost primjene znanja u praksi, istraživačke vještine, sposobnost učenja, sposobnost prilagodbe novoj situaciji, sposobnost proizvodnje novih ideja (kreativnost), razumijevanje stranih kultura i zemalja te briga za kvalitetu. ${ }^{27}$

\section{Zaključak}

Osobine dobro uspostavljenog radnog kolektiva jesu empatija i međusobno razumijevanje, suradnja, otvorena komunikacija, jasno postavljene norme, želja za poboljšanjem, grupna i osobna samosvijest, inicijativa i proaktivno rješavanje problema, fleksibilnost, samopouzdanje, organizacijska svijest, uspostavljanje veza s drugim timovima, naglašena lojalnost skupini i rad koji je sam po sebi zabavan i ispunjava. ${ }^{28} \mathrm{U}$ svakoj knjižnici postoji svojevrsna „organizacijska kultura“, odnosno obrazac ponašanja, zajedničkih uvjerenja i vrijednosti pripadnika jedne organizacije. Ona nam govori što ljudi misle, kako rade, čemu teže te na koji se način u ustanovi ponašaju. Stavovi i uvjerenja upravitelja određuju pravac razvoja knjižnice te utječu na cjelokupno poslovanje. Organizacijska kultura ključna je za razvoj knjižnice. Način, stil vođenja i pristup vođenju ustanove, odnos upravitelja prema inovaciji, promjenama i kompetencijama djelatnika, izravno utječe na smjer razvoja knjižnice. Organizacijska kultura najjasnije je vidljiva kroz upravljanje ljudskim potencijalima. ${ }^{29}$ Svaki uspješan ravnatelj, pored asertivnosti i emocionalne inteligencije, mora posjedovati organizacijske, menadžerske i

\footnotetext{
26 Machala, Dijana. Knjižničarske kompetencije : pogled na razvoj profesije. Zagreb : NSK, 2015. Str. 231.

27 Barbarić, Ana. Knjižničarske kompetencije. // Cjeloživotno učenje knjižničara : ishodi učenja i fleksibilnost / ur. Aleksandra Horvat i Dijana Machala. Zagreb : NSK, 2009. Str. 62.

28 Goleman, Daniel. Emocionalna inteligencija u poslu. Zagreb : Mozaik knjiga, 2008. Str. 210.

29 Petr Balog, Kornelija; Martina Dragija Ivanović; Kristina Feldvari. Percepcija kvalitete 'iznutra' : razgovori s ravnateljima narodnih i voditeljima visokoškolskih knjižnica. // Vjesnik bibliotekara Hrvatske 53, 3/4 (2011), str. 2. Dostupno i na http://hrcak.srce.hr/80502 [citirano: 2017-06-17].
} 
interpersonalne komunikacijske vještine. Organizacijske komunikacijske vještine jesu poticanje otvorene rasprave, rješavanje konflikata, stvaranje informacijskih mreža i pregovaranje. Menadžerske su komunikacijske vještine poticanje entuzijazma, kataliziranje promjena, kreiranje grupne sinergije, izgradnja timskih veza te motiviranje. Interpersonalne komunikacijske vještine jesu aktivno slušanje, samokontrola, izgradnja povjerenja, povezivanje s ljudima i uvažavanje drugih ljudi. ${ }^{30}$ Osoba koja upravlja knjižnicom treba imati samopouzdanja i samopoštovanja, mora biti odgovorna i korektna, spremna na suradnju i tolerantna te mora imati dobro razvijene socijalne vještine. Osobne kompetencije informacijskih profesionalaca ogledaju se kroz učinkovitu komunikaciju, jasnu prezentaciju ideja i pregovaračko umijeće. Nužno je graditi atmosferu međusobnog poštovanja i suradnje, poštovati različitosti, jasno prezentirati ideje, uvjerljivo pregovarati te prepoznavati važnost profesionalnog umrežavanja. ${ }^{31}$

\section{LITERATURA}

Agada, John; Kenneth Weaver. Empathy, assertiveness and professional socialization in library education [citirano: 2016-02-01]. Dostupno na http://rportal.lib.ntnu.edu. tw/bitstream/77345300/15589/1/ntnulib_ja_A1201_2302_001.pdf

Ames, Daniel. Pushing up to a point : assertiveness and effectiveness in leadership and interpersonal dynamics [citirano: 2016-02-01]. // Research in Organizational Behavior 29 (2009), 112-133. Dostupno na http://www.columbia.edu/ da358/publications/ames_pushing_up_to_a_point.pdf

Barbarić, Ana. Knjižničarske kompetencije. // Cjeloživotno učenje knjižničara : ishodi učenja i fleksibilnost / ur. Aleksandra Horvat i Dijana Machala. Zagreb : NSK, 2009. Str. 57-69.

Special Library Association. Competencies for information professionals of the 21st century. [citirano: 2016-02-01]. Dostupno na https://www.sla.org/wp-content/uploads/2013/01/0_LRNCompetencies2003_revised.pdf

Conrad, David; Robert Newberry. 24 business communication skills : attitudes of human resource managers versus business educators [citirano: 2016-02-01]. // Ame-

30 Conrad, David; Robert Newberry. 24 business communication skills : attitudes of human resource managers versus business educators [citirano: 2016-02-01]. // American Communication Journal 13, 1 (2011), str.11. Dostupno na http://ac-journal.org/journal/pubs/2011/spring/ConradNewberry.pdf.

31 Competencies for Information Professionals of the 21 st Century. Special Library Association [citirano: 2016-02-01]. Dostupno na https://www.sla.org/wp-content/uploads/2013/01/0_LRNCompetencies2003_revised.pdf. 
rican Communication Journal 13, 1 (2011), 4-23. Dostupno na http://ac-journal.org/ journal/pubs/2011/spring/ConradNewberry.pdf

Cornelius, E. T. Leadership styles for dealing with people [citirano: 2016-02-01]. Dostupno na https://www.yumpu.com/en/document/view/10187170/leadership-styles-for-dealing-with-people-collegiate-project-

Goleman, Daniel. Emocionalna inteligencija : zašto može biti važnija od kvocijenta inteligencije. Zagreb : Mozaik knjiga, 1997.

Goleman, Daniel. Emocionalna inteligencija u poslu. Zagreb : Mozaik knjiga, 2008.

Handbook on communication skills [citirano: 2016-02-01]. Dostupno na http://www. slideshare.net/RDC2/handbook-on-communication-skills

Heathfield, Susan. M. What is human resource management [citirano: 2016-02-01]. Dostupno na http://humanresources.about.com/od/glossaryh/f/hr_management.htm

Hulbert, Doris. Assertive management in libraries [citirano: 2016-02-01]. // Journal of Academic Librarianship 16, 3 (1990). Str. 158-162. Dostupno na http://cdigital. uv.mx/bitstream/123456789/5949/1/Al2.pdf

Lewicki, Roy. J; David M. Saunders; Bruce Barry. Pregovaranje. 5. izd. Zagreb : Mate, 2009.

Lukačević, Srđan; Kornelija Petr Balog; Dubravka Pađen Farkaš. Asertivnost i komunikacija u knjižničnom okruženju: primjer Gradske i sveučilišne knjižnice Osijek. // Libellarium 9, 1 (2016), 89-110. Dostupno i na http://libellarium.org/index.php/ libellarium/article/view/245 [citirano: 2017-06-17].

Lukačević, Srđan; Kornelija Petr Balog. Trebamo li mijenjati svoje komunikacijske vještine? Primjer Gradske i sveučilišne knjižnice Osijek. // Vjesnik bibliotekara Hrvatske 56, 1-2 (2013), 153-169. Dostupno i na http://hrcak.srce.hr/index.php?show=clanak\&id_clanak_jezik=170275 [citirano: 2017-06-17].

Machala, Dijana. Knjižničarske kompetencije : pogled na razvoj profesije. Zagreb : NSK, 2015.

Machala, Dijana. Knjižničarske kompetencije. // Cjeloživotno učenje knjižničara : ishodi učenja i fleksibilnost / ur. Aleksandra Horvat i Dijana Machala. Zagreb : NSK, 2009. Str. 83-125.

Machala, Dijana; Tatjana Nebesny; Aleksandra Horvat. Kompetencijska matrica. // Cjeloživotno učenje knjižničara : ishodi učenja i fleksibilnost / ur. Aleksandra Horvat i Dijana Machala. Zagreb : NSK, 2009. Str. 125-135.

Petr Balog, Kornelija; Ivana Martinović. Na tragu ishoda učenja: kompetencije diplomiranih knjižničara Odsjeka za informacijske znanosti u Osijeku. // Vjesnik bibliotekara hrvatske 52, 1 (2010), 1-17. Dostupno i na http://hrcak.srce.hr/index.php?show=clanak\&id_clanak_jezik=123548 [citirano: 2017-06-17].

Petr Balog, Kornelija; Martina Dragija Ivanović; Kristina Feldvari. Percepcija kvalitete 'iznutra' : razgovori s ravnateljima narodnih i voditeljima visokoškolskih knjižnica. 
// Vjesnik bibliotekara Hrvatske 53, 3/4 (2011), 1-24. Dostupno i na http://hrcak. srce.hr/80502 [citirano: 2017-06-17].

Swapna G.; B. S. Biradar. Competencies for library professionals in digital environment. // e-Library Science Research Journal 5, 2 (2016), 1-5. Dostupno i na http:// lsrj.in/UploadedArticles/764.pdf [citirano: 2017-06-17].

Upravljanje ljudskim potencijalima [citirano: 2016-02-01]. Dostupno na http://www. poslovniforum.hr/management/upravljanje_ljudskim_potencijalima.asp

Vodopija, Štefanija. Opća i poslovna komunikacija : priručnik i savjetnik za uspješnu komunikaciju. Rijeka : Naklada Žagar, 2006. 